\title{
EVALUATION OF THE BEHAVIOUR OF LIME AND CEMENT BASED MORTARS EXPOSED AT ELEVATED TEMPERATURES
}

\author{
VASILIKI PACHTA $^{1 *}$ AND MARIA STEFANIDOU ${ }^{1}$ \\ ${ }^{1}$ Laboratory of Building Materials, School of Civil Engineering \\ Aristotle University of Thessaloniki, 54124, Thessaloniki, Greece \\ e-mail:vpachta@civil.auth.gr, stefan@civil.auth.gr
}

Keywords: Mortars, Elevated temperature, Fire, Lime, Cement

\begin{abstract}
Exposure to fire and elevated temperatures is diachronically a significant decay factor, influencing the stability of structures. Cement and lime-based mortars have a different behavior when exposed at elevated temperatures, usually testified by the post-fire preservation state of historic and contemporary constructions. In this paper, the correlation of their properties is envisaged, in order to identify the key elements of their performance. To this direction, five compositions of cement and lime based mortars were manufactured and tested, after their exposure at $200^{\circ} \mathrm{C}, 400^{\circ} \mathrm{C}, 600^{\circ} \mathrm{C}, 800^{\circ} \mathrm{C}$ and $1000^{\circ} \mathrm{C}$. The binders used concerned CEM I42.5N $(C)$, hydrated lime $(L)$ and natural pozzolan $(P)$, while the systems applied regarded $C, C: L$ (1:1), $L, L: P(1: 1)$ and $L: P: C$ (1:0.8:0.2) (parts per weight). The aggregates used were natural of siliceous origin and their gradation varied from $0-4 \mathrm{~mm}$ to $0-8 \mathrm{~mm}$. The $B / A$ ratio was $1 / 2$ by weight and the $W / B$ ratio was adjusted in order to maintain workability around $15 \pm 1 \mathrm{~cm}$. The physico-mechanical properties of the specimens, were recorded before and after their exposure at the selected temperatures. From the evaluation of the results, it was concluded that the mortars' behavior was different at the early temperature rate (up to $600^{\circ} \mathrm{C}$ ) according to their type, whereas the results were more comparable at the extreme temperature level. Generally it was observed that although the initial strength of the lime-based mortars was low (1-4MPa), they presented a more stable and efficient performance at the elevated temperatures, rendering them probably more resistant at the first stages of fire actions. Cementbased mortars seemed to present a better performance at the highest temperatures of $800^{\circ} \mathrm{C}$ and $1000^{\circ} \mathrm{C}$.
\end{abstract}

\section{INTRODUCTION}

Fire has been diachronically a significant decay factor of historic and modern structures, leading to extreme damages and loss of their stability. The post-fire state of constructions maybe related to several factors, such as the fire characteristics (i.e. heating rate, fire duration, maximum temperature), the ground plan of the building, as well as the type and properties of building materials.

The influence of fire on concrete has been studied from the beginning of the $20^{\text {th }}$ century (1922) [1], while during the last decades research has been induced [2-6]. Researchers focus on various assets, such as the analysis of fire scenarios (heating rate, exposure temperature and time), the performance of building materials at elevated temperatures, the design and testing of 
fire-resistant materials, as well as the development and application of post-fire assessment and repair strategies [4-10]. Relevant Standards and Recommendations exist, providing accumulated data (RILEM TC 129-MHT, RILEM TC 200-HTC, EN 1991-1-2 Eurocode 1, EN 1992 Eurocode 2, ISO 834-11:2014, BS 476-3:2004) [10-15].

The temperature/time development curves, as given by the Standards (Fig. 1), show that the maximum temperature attained during a fire, is around $1100-1200^{\circ} \mathrm{C}$, while the temperature rate may vary [16]. During the first 30 minutes of the action, temperature is rapidly increased up to $822^{\circ} \mathrm{C}$. Due to the difficulty of simulating such an extreme temperature rate at laboratory level and in order to study the performance of building materials at elevated temperatures, researchers propose a development rate ranging from 5 to $10^{\circ} \mathrm{C} / \mathrm{min}$ [1-9].

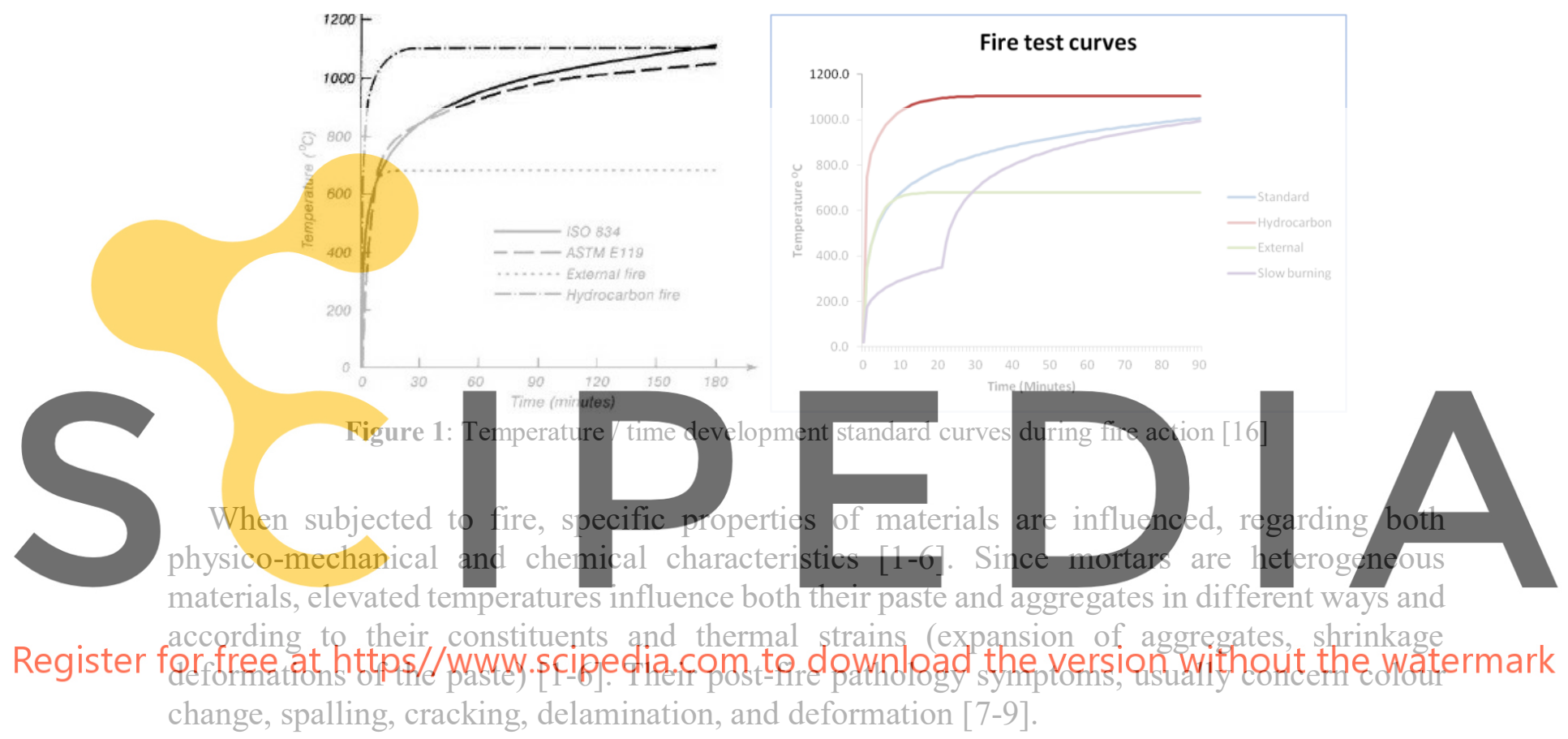

According to literature, between $100-200^{\circ} \mathrm{C}$, the free moisture of the materiais evaporates, while above $250^{\circ} \mathrm{C}$ the dehydration or loss of the bonded water begins [1-6]. Above $300^{\circ} \mathrm{C}$ the silicate hydrates of the cement paste $(\mathrm{C}-\mathrm{S}-\mathrm{H}$ gel $)$ decompose and above $500^{\circ} \mathrm{C}$ portlandite, influencing the stability of the matrix [4]. Aggregates function according to their origin, whereas siliceous aggregates seem to be more resistant than calcareous ones [4].

In the case of cement-based mortars, the residual strength is maintained for temperatures up to $300^{\circ} \mathrm{C}$, while between $300^{\circ} \mathrm{C}$ and $500^{\circ} \mathrm{C}$ it is decreased around $15-40 \%$ [1-6]. Above 550$600^{\circ} \mathrm{C}$, it is minimized and secondary chemical reactions occur (decarbonisation of carbonates in both the cement paste and the aggregates) [4]. Usually above $800^{\circ} \mathrm{C}$, complete disintegration of the constituents begins.

In the case of lime-based mortars [7, 17], compressive strength is significantly increased up to $600^{\circ} \mathrm{C}$ (almost doubled). It is reduced at $800^{\circ} \mathrm{C}$ (around $50 \%$ of the initial value) and minimized at $1000^{\circ} \mathrm{C}$. Generally, lime-based mortars exhibit a good performance throughout the tested temperatures, maintaining their mass and volume until $1000^{\circ} \mathrm{C}$. 
In the present paper, an effort has been made to comparatively study the performance of cement and lime-based mortars at elevated temperatures. To this direction, five compositions were manufactured and exposed at $200^{\circ} \mathrm{C}, 400^{\circ} \mathrm{C}, 600^{\circ} \mathrm{C}, 800^{\circ} \mathrm{C}$ and $1000^{\circ} \mathrm{C}$. The binders used concerned CEM I42.5N (C), hydrated lime (L) and natural pozzolan (P), while the systems applied regarded C, C:L, L, L:P and L:P:C.

The purpose of the study was to envisage the behaviour of contemporary and traditional binding systems, found in mortars of modern or historic structures. Repaired historic constructions are also related, where traditional and cement based materials coexist, due to improper restoration works or specific demands.

\section{MATERIALS AND METHODS}

During the experimental work, five compositions of cement and lime-based mortars were manufactured and tested. The binding agents used concerned CEM I42.5N, hydrated lime (L) and natural pozzolan (P), while the systems applied regarded C, C:L (1:1), L, L:P (1:1) and L:P:C (1:0.8:0.2). The aggregates were natural of siliceous origin and their gradation varied from $0-4 \mathrm{~mm}$ to $0-8 \mathrm{~mm}$.

In order to reduce the water demand, a sulphate free, polycarboxylate superplasticizer was added in a proportion of $1 \% \mathrm{w} / \mathrm{w}$ of binders. The Water/Binder (W/B) ratio was adjusted for achieving workability of $15 \pm 1 \mathrm{~cm}$, according to EN1015-3. The manufacture and curing of the mortar specimens was according to EN1015-11, while totally 16 specimens (dimensions

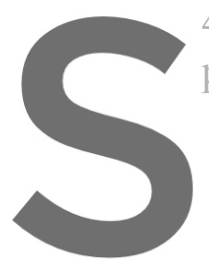
$4 \times 4 \times 16 \mathrm{~cm})$ of each com

proportions of the morta

Raw materials
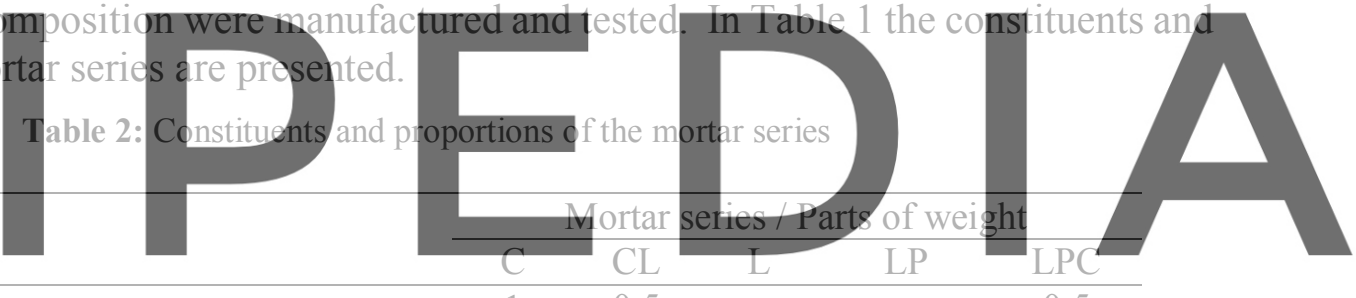

Cement I 42.5

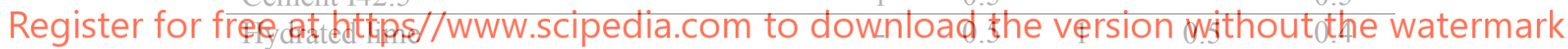

\begin{tabular}{lccccc}
\hline Natural pozzolan & - & - & - & 0.5 & 0.1 \\
\hline Sand of siliceous origin, pale colour $(0-4 \mathrm{~mm})$ & 2 & 2 & 1.4 & 1.4 & 1.4 \\
\hline Gravel of siliceous origin (4-8mm) & - & - & 0.6 & 0.6 & 0.6 \\
\hline Super plasticizer (1\% w/w of binders) & $\sqrt{ }$ & $\sqrt{ }$ & $\sqrt{ }$ & $\sqrt{ }$ & $\sqrt{ }$ \\
\hline W/B ratio & 0.36 & 0.44 & 0.85 & 0.57 & 0.54 \\
\hline Workability $(\mathrm{cm})$ (EN1015-3:1999) & 15.5 & 15.0 & 14.8 & 15.5 & 14.7 \\
\hline
\end{tabular}

Twenty-eight days after their manufacture, the physico-mechanical properties of the mortar compositions were recorded, regarding porosity and apparent specific gravity (RILEM CPC 11.3), water absorption coefficient due to capillary action (EN 1015-18:2002), dynamic modulus of elasticity (BS 1881-203:1986), flexural and compressive strength (EN101511:1999).

Two specimens of each mortar composition were subjected to elevated temperatures $\left(200^{\circ} \mathrm{C}\right.$, $400^{\circ} \mathrm{C}, 600^{\circ} \mathrm{C}, 800^{\circ} \mathrm{C}$ and $1000^{\circ} \mathrm{C}$ ), according to former research work [7, 9, 17]. For the experiment, an electric furnace was used, where the temperature rate and duration time could be manually set (Fig. 2). The heating scheme followed (maximum temperature, heating rate, exposure time and cooling rate) was based on former research work [7, 9, 17] and was aligned 
with relevant research [1-6]. The methodology concerned heating rate $5^{\circ} \mathrm{C} / \mathrm{min}$, exposure duration to the maximum temperature $2 \mathrm{~h}$ and cooling rate $2^{\circ} \mathrm{C} / \mathrm{min}$ (Fig.2).
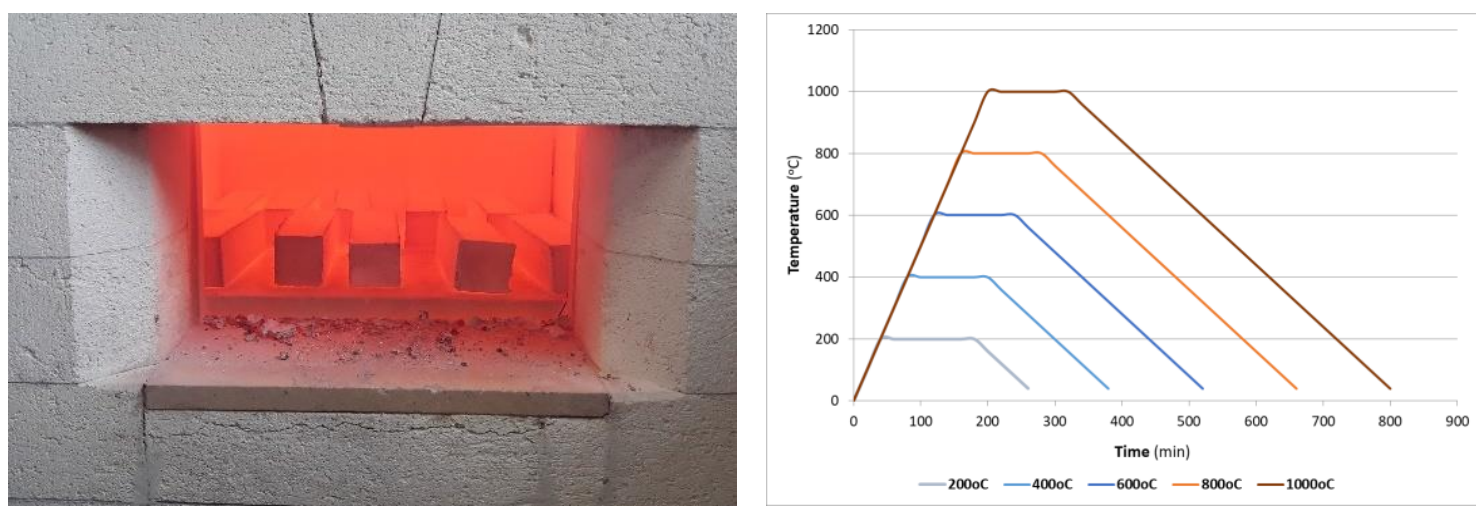

Figure 2: Electric furnace (left) and heating scheme (rate, exposure time, cooling rate) (right)

After the exposure to each temperature, the specimens maintained for $24 \mathrm{~h}$ at laboratory conditions and their weight and dimensions were recorded, in order to estimate their mass and volume changes. Their physico-mechanical characteristics were tested, regarding porosity, apparent specific gravity, dynamic modulus of elasticity, flexural and compressive strength. Macroscopic observation of the specimens and colour determination (according to the Munsell

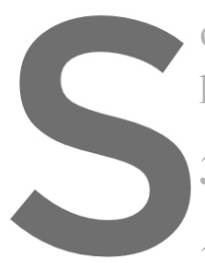
chart) were also attain performance at elevated

\section{RESULTS AND DIS}

3.1 Physico-mechanicall charateristics
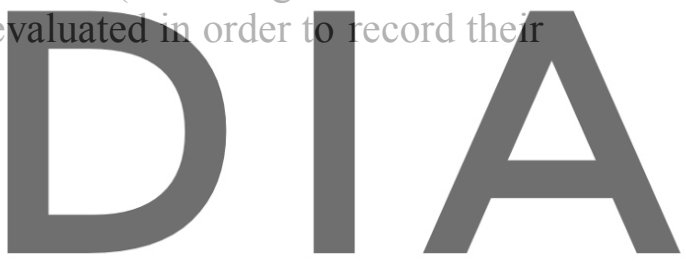

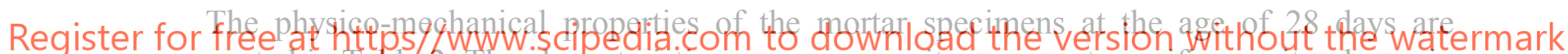
presented in Table 2. The characteristics concern porosity, apparent specific gravity, dynamic modulus of elasticity, flexural and compressive strength, while the water absorption coefficient due to capillary action is presented in Figure 3.

Table 2: Physico-mechanical properties of the mortar compositions at the age of 28 days

\begin{tabular}{cccccc}
\hline $\begin{array}{c}\text { Mortar } \\
\text { series }\end{array}$ & $\begin{array}{c}\text { Porosity } \\
(\%)\end{array}$ & $\begin{array}{c}\text { Ap. Spec. } \\
\text { Gravity }\end{array}$ & $\begin{array}{c}\text { Dyn. Mod. of } \\
\text { Elasticity } \\
(\mathrm{GPa})\end{array}$ & $\begin{array}{c}\text { Flexural } \\
\text { strength } \\
(\mathrm{MPa})\end{array}$ & $\begin{array}{c}\text { Compressive } \\
\text { strength } \\
(\mathrm{MPa})\end{array}$ \\
\hline C & 8.68 & 2.15 & 37.55 & 9.93 & 60.79 \\
\hline CL & 18.8 & 1.93 & 25.11 & 6.01 & 17.46 \\
\hline L & 30.86 & 1.65 & 1.36 & 0.12 & 0.87 \\
\hline LP & 16.66 & 1.84 & 13.32 & 1.12 & 3.15 \\
\hline LPC & 16.15 & 1.90 & 16.22 & 1.70 & 4.20 \\
\hline
\end{tabular}




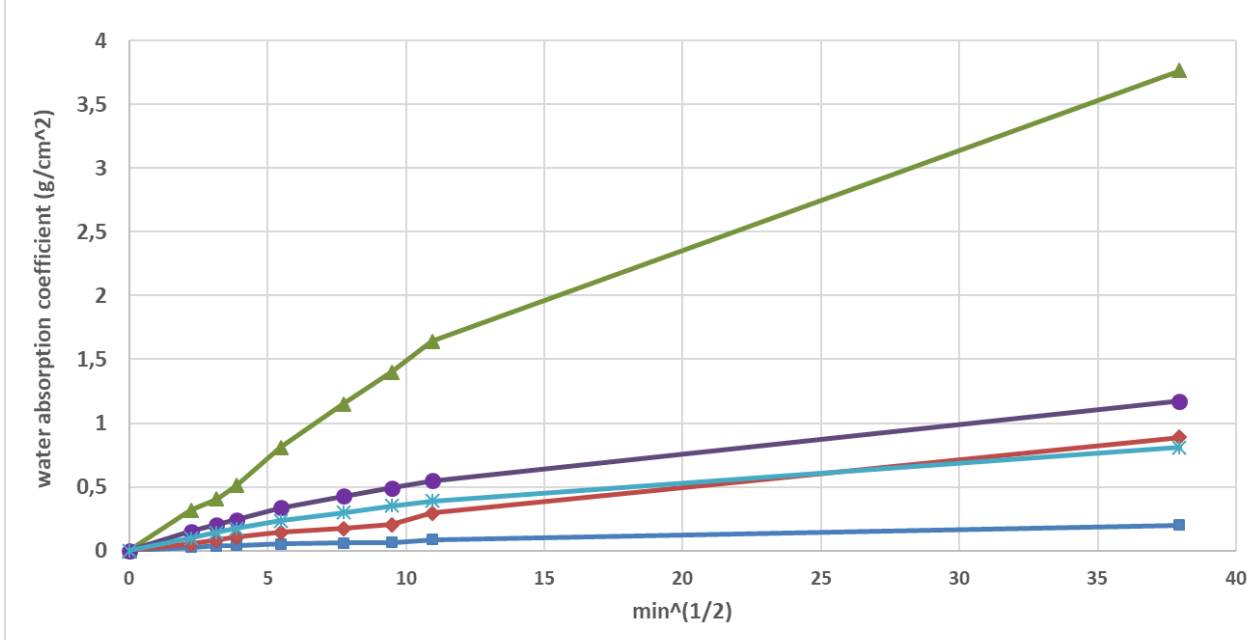

Figure 3: Water absorption coefficient of the mortar compositions (28d)

From the evaluation of the results (Table 2) it was asserted that with the substitution of 50\% of cement with lime (CL), the porosity was doubled (18.8\%), while the mechanical characteristics, especially compressive strength, were significantly decreased. Flexural strength dropped from 9.93MPa (C) to 6.01MPa (CL) and compressive strength from $60.79 \mathrm{MPa}$ (C) to

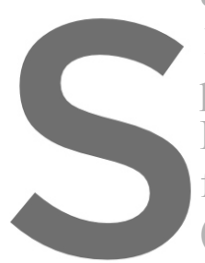
17.46MPa (CL), In the pozzolan (LP) resulted Flexural strength was in from $0.87 \mathrm{MPa}$ (L) to 3.1 (LPC), slightly decrease
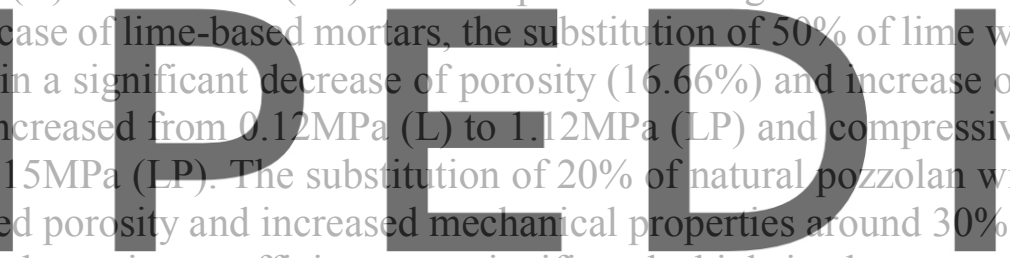

As expected, water absorption coefficient was significantly high in the case of the lime

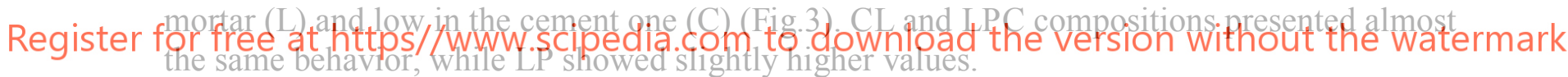

\subsection{Performance at elevated temperatures}

The performance of the mortar compositions was recorded after their exposure at the elevated temperatures $\left(200^{\circ} \mathrm{C}, 400^{\circ} \mathrm{C}, 600^{\circ} \mathrm{C}, 800^{\circ} \mathrm{C}\right.$ and $\left.1000^{\circ} \mathrm{C}\right)$. Their physico-mechanical properties, regarding volume and mass change, color alterations, porosity, apparent specific gravity, dynamic modulus of elasticity, flexural and compressive strength, were comparatively evaluated.

The volume change of the specimens presented the same trend in all compositions (Fig. 4). At $200^{\circ} \mathrm{C}$, a short expansion was observed, which was more intense for composition L $(3.6 \%)$, while at $400^{\circ} \mathrm{C}$ a volume decrease was recorded ranging from 0.5 to $5 \%$. The lowest values were recorded for $\mathrm{C}$ and CL compositions. At $600^{\circ} \mathrm{C}$ and $800^{\circ} \mathrm{C}$ a slight volume increase was observed for L, LP and LPC, while C and CL showed volume reduction. At $1000^{\circ} \mathrm{C}$ all volume change was minimized. Compared to all compositions, $\mathrm{C}$ presented the more extreme volume loss above $400^{\circ} \mathrm{C}$, ranging from $1.5-4.5 \%$.

Regarding mass change (Fig.5), all compositions, except C, presented the same trend, with decreasing values from 200 to $1000^{\circ} \mathrm{C}(7-21 \%)$. The highest decrease was observed for $\mathrm{L}$. 
Composition $\mathrm{C}$ presented a different behavior with a slight mass increase at $200^{\circ} \mathrm{C}$ and further reduction. The highest mass loss was recorded at $400^{\circ} \mathrm{C}(4.6 \%)$.

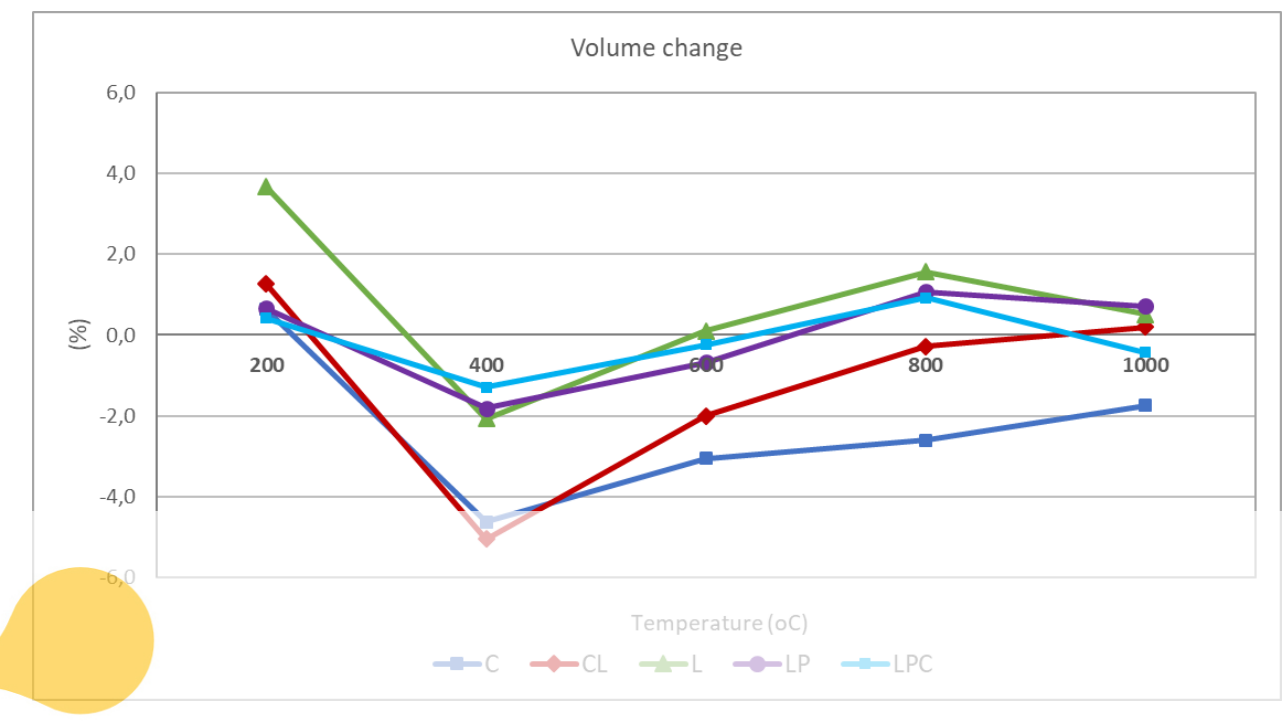

Figure 4: Volume change of the mortar specimens, exposed at elevated temperatures
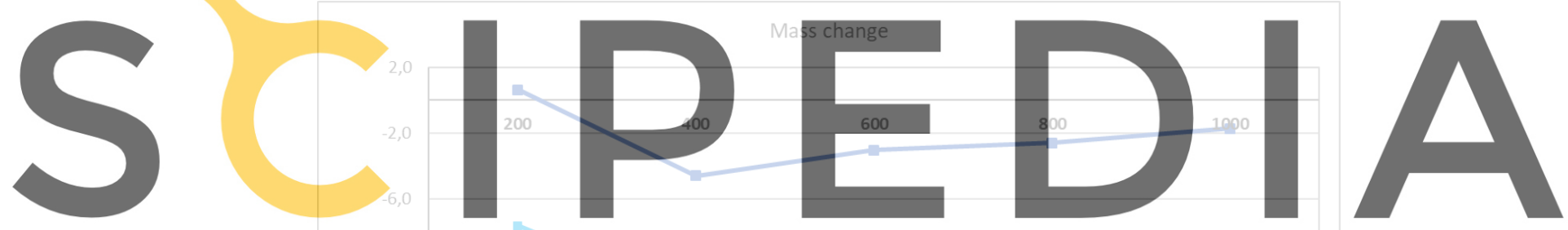

Register for free at https//www.scipedia.com to download the version without the watermark

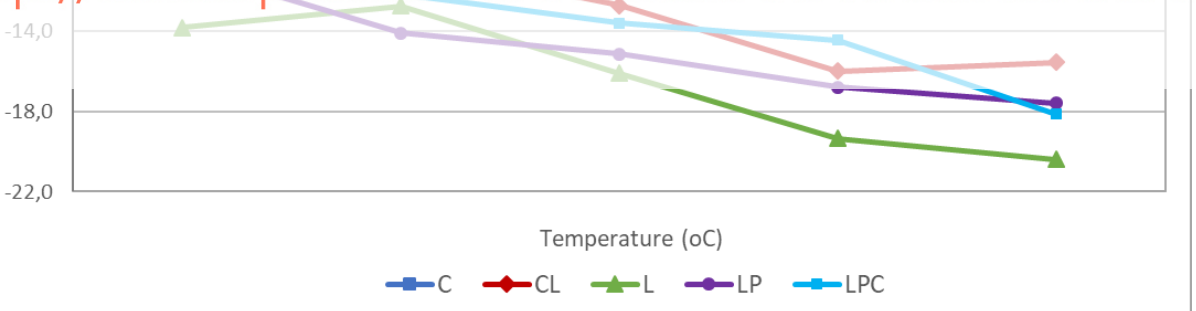

Figure 5: Mass change of the mortar specimens, exposed at elevated temperatures

Regarding porosity and apparent specific gravity (Fig.6), the performance of the specimens presented some similarities. Porosity was generally increased up to $600^{\circ} \mathrm{C}$ (except of L) in all cases. $\mathrm{C}$ had the highest increase up to $800^{\circ} \mathrm{C}$ with values ranging from 8 to $25 \%$ (at $1000^{\circ} \mathrm{C}$ there was a decrease to $20 \%$ ). CL presented a lower increase up to $600^{\circ} \mathrm{C}$ from 20 to $30 \%$. LP and LPC had the same behavior with an increase from 18 to $34 \%$ up to $600^{\circ} \mathrm{C}$ and a further decrease. Composition $\mathrm{L}$ presented the lower fluctuations at all temperatures, with a short decrease of values (31-28\%). Apparent specific gravity was reduced throughout the elevated temperatures (10-15\%). The greatest fluctuations were recorded in compositions $\mathrm{C}$ and $\mathrm{L}$. 

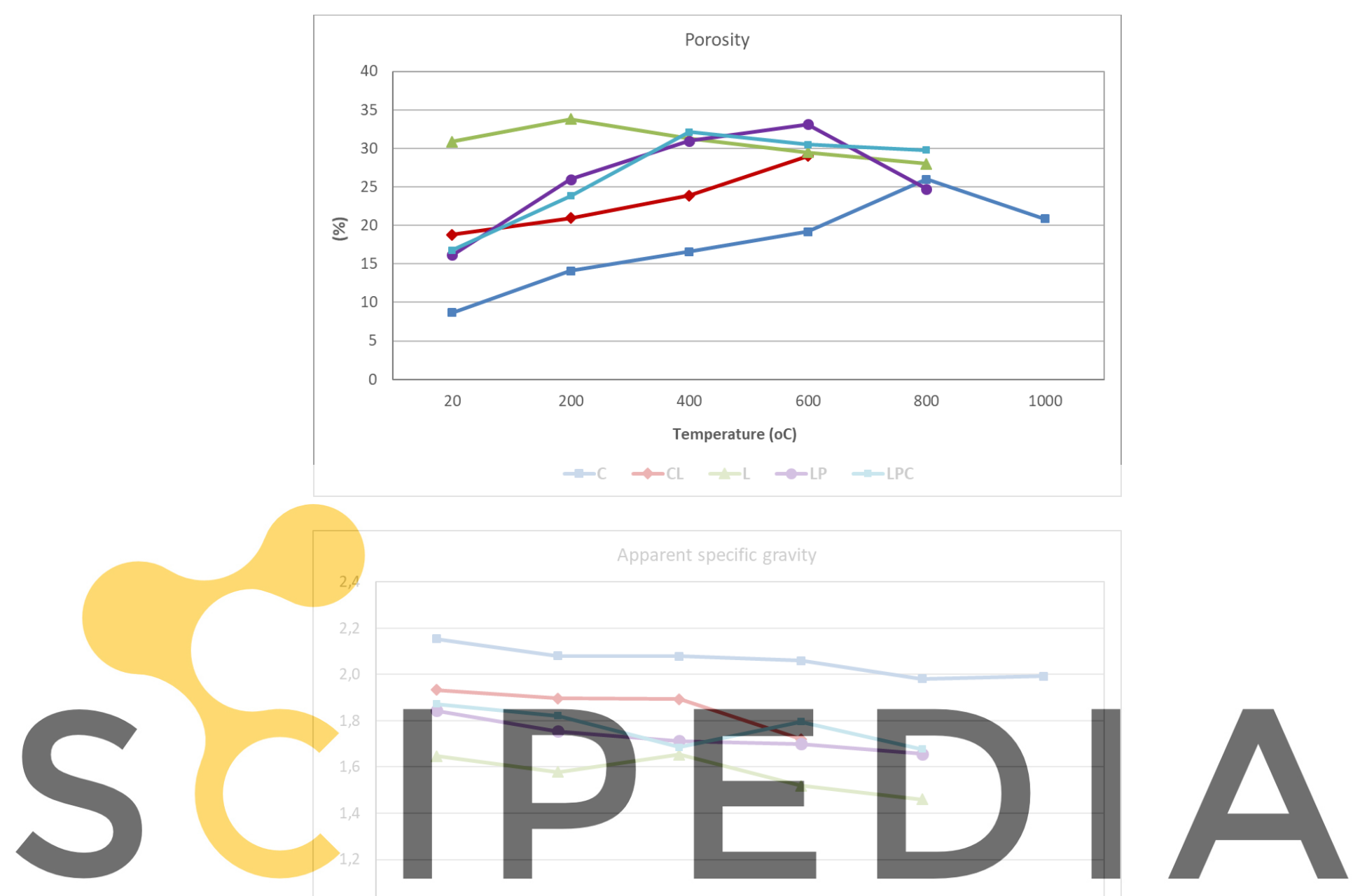

Register for free at https//www.scipedia.com to downlogad the version without the watermark

Figure 6: Porosity and Ap. Specific gravity of the mortar specimens, exposed at elevated temperatures

Concerning the mechanical properties of the mortar specimens, it was generally observed that dynamic modulus of elasticity was decreased throughout the temperature increase (Fig.7). At $200^{\circ} \mathrm{C}$, compositions $\mathrm{C}$ and $\mathrm{CL}$ presented a decrease of the initial values around $25-30 \%$, while LP and LPC showed a reduction of $10-15 \%$. At $400^{\circ} \mathrm{C}$ there was a further decrease around $45 \%$ for $\mathrm{C}$ and $\mathrm{CL}$ and $70 \%$ for $\mathrm{LP}$ and $\mathrm{LPC}$, while at $600^{\circ} \mathrm{C}$ and further all values where minimized. Composition $\mathrm{L}$, presented a different behavior, maintaining the initial value up to $600^{\circ} \mathrm{C}$. 


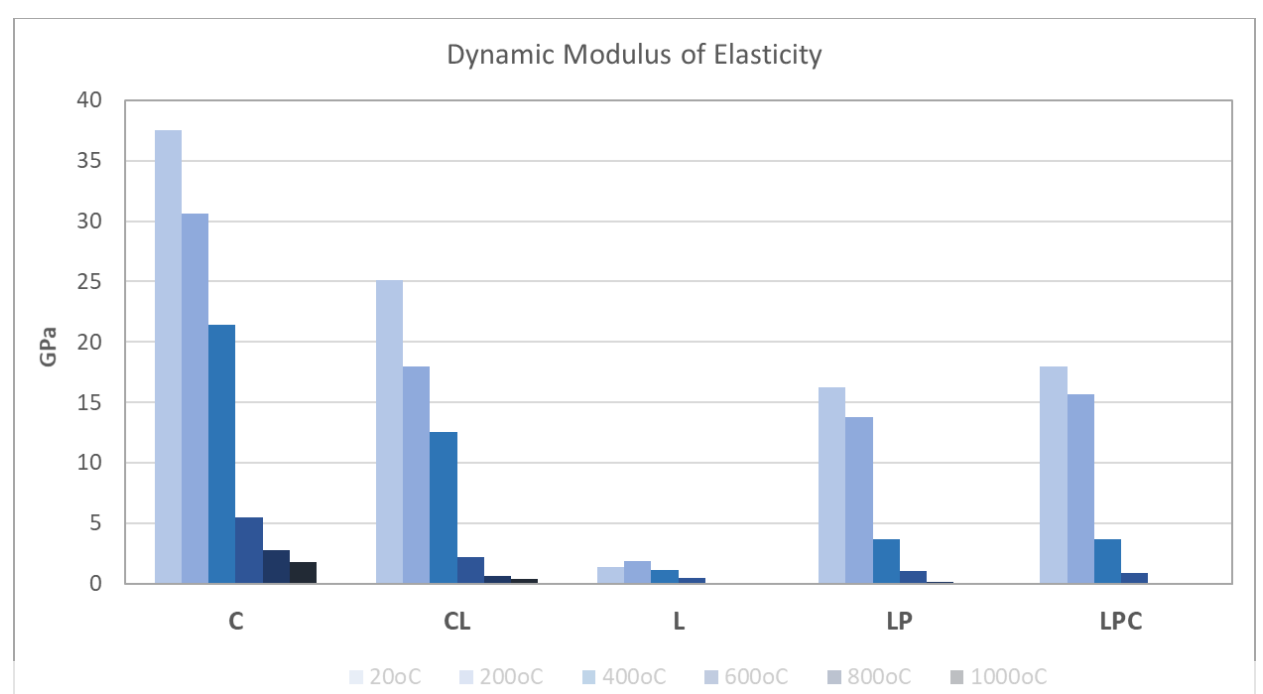

Figure 7: Dynamic Modulus of Elasticity of the mortar specimens, exposed at elevated temperatures

In flexural strength (Fig.8), compositions had a different behavior, according to their type. Although the values were decreased throughout the elevated temperatures for $\mathrm{C}$, in the rest compositions there was a strength increase at $200^{\circ} \mathrm{C}$ (mainly in CL). The values were further decreased, especially above $600^{\circ} \mathrm{C}$. In composition L, values maintained at a low level

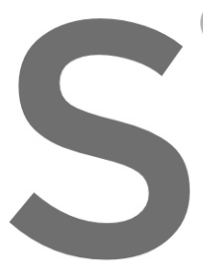
$(\sim 0.3 \mathrm{MPa})$ throughou
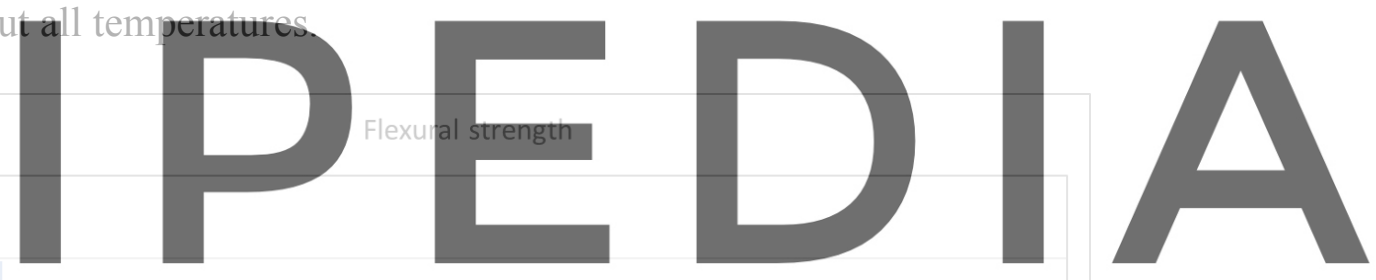

Register for free at https//www.scipedia.com to download the version without the watermark

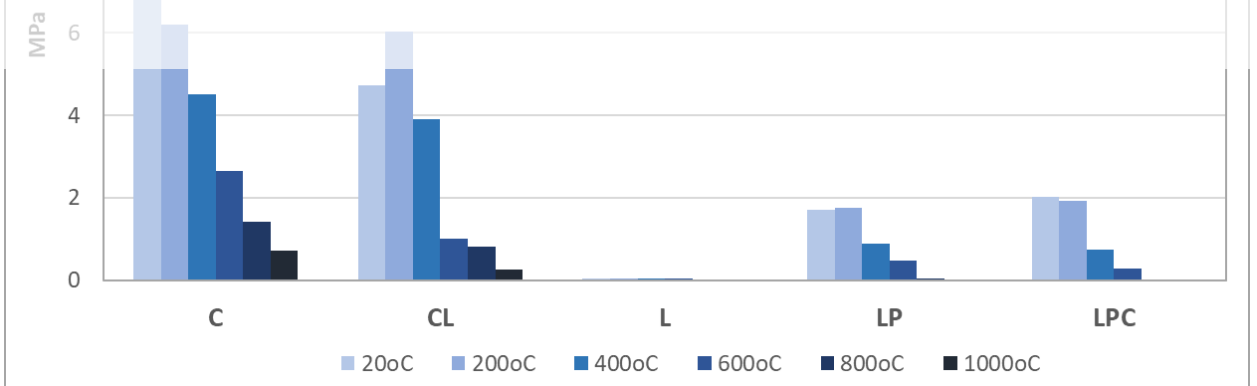

Figure 8: Flexural strength of the mortar specimens, exposed at elevated temperatures

Compressive strength values (Fig.9), also presented fluctuations among the compositions. As it is presented in Figure 10, C showed a gradual (almost linear) strength loss throughout all temperatures $\left(30 \%\right.$ at $400^{\circ} \mathrm{C}$ and $45 \%$ at $\left.600^{\circ} \mathrm{C}\right)$ leading to a final loss of $85 \%(61 \rightarrow 10 \mathrm{MPa})$. Composition CL had a strength increase at 200 and $400^{\circ} \mathrm{C}(30-40 \%)$, while it was significantly reduced at $600^{\circ} \mathrm{C}(\sim 50 \%)$ and minimized at $1000^{\circ} \mathrm{C}(17.5 \rightarrow 4.5 \mathrm{MPa})$. Compositions L, LP and LPC showed a strength increase up to $600^{\circ} \mathrm{C}$ (around 20-100\%) and a further strength decrease 
at 800 and $1000^{\circ} \mathrm{C}$. The highest strength increase was observed for LP at $400^{\circ} \mathrm{C}(100 \%)$, while the lowest loss was shown for $\mathrm{L}$ at 800 and $1000^{\circ} \mathrm{C}(20-30 \%)$.

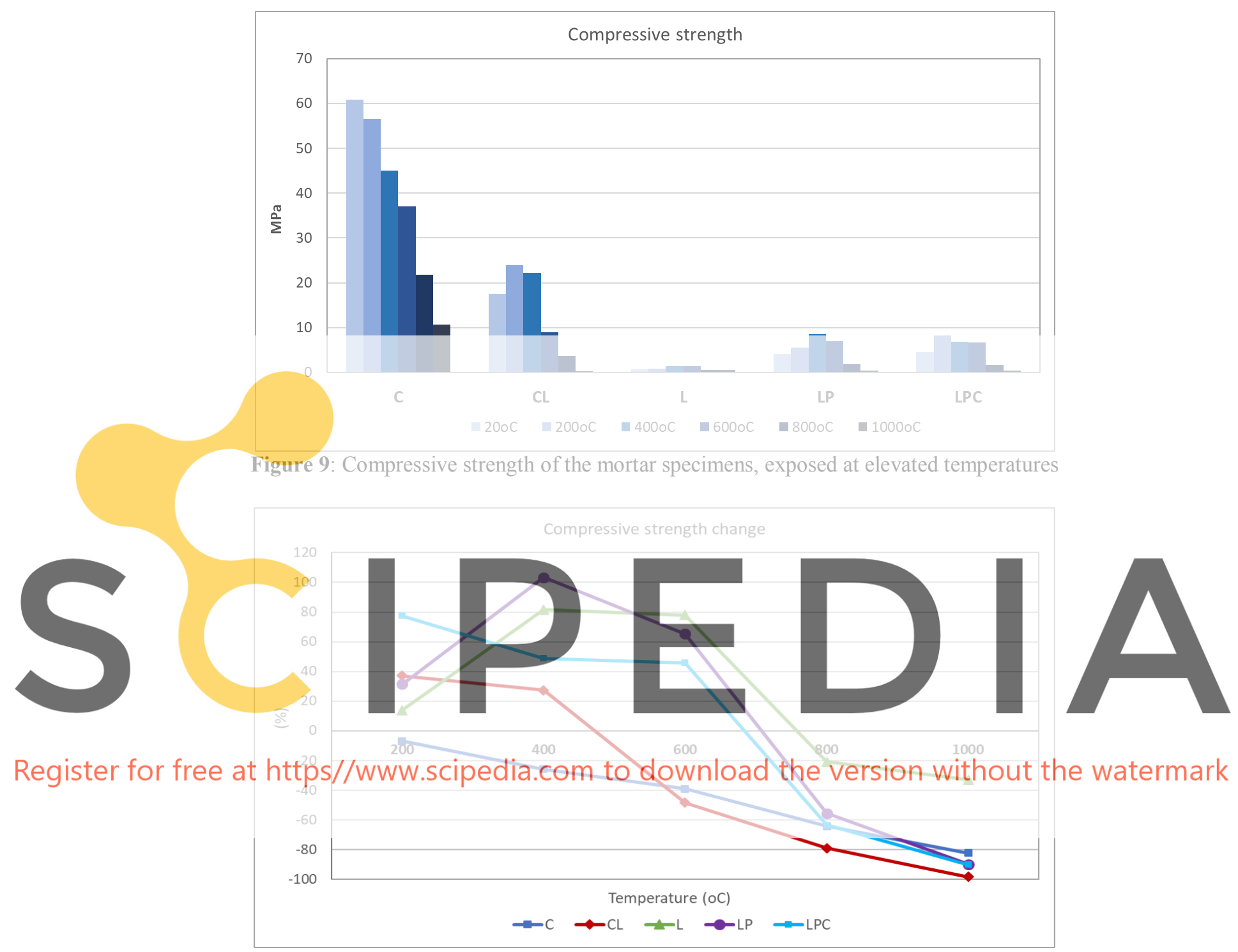

Figure 10: Compressive strength changes of the mortar specimens, exposed at elevated temperatures

The structure of the specimens, after their exposure at the elevated temperatures was generally maintained, as presented in Figure 11 . At $600^{\circ} \mathrm{C}$ limited spalling and color alterations were observed, which were more intense at 800 and $1000^{\circ} \mathrm{C}$. Composition L was cracked at 800 and severely damaged at $1000^{\circ} \mathrm{C}$, while $\mathrm{LPC}$ also presented extreme damages at $1000^{\circ} \mathrm{C}$. Regarding the more extreme color changes (according to the Munsel scale), compositions $\mathrm{C}$ and CL were converted from GLEY 2, 7/1 light bluish gray and GLEY 2, 8/1 light bluish gray respectively to GLEY 2, 8/1 light greenish gray. 


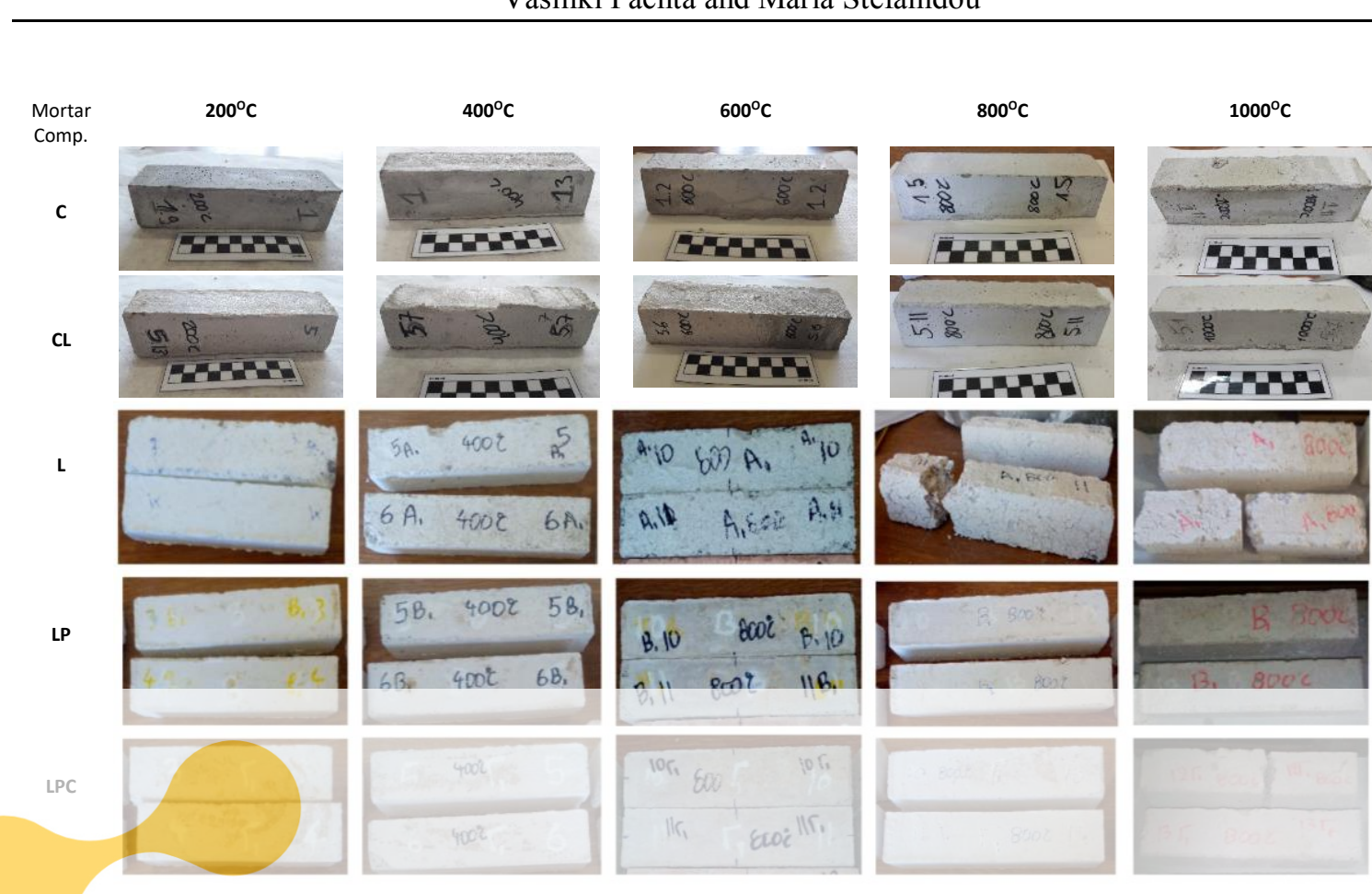

Figure 11: Macroscopic photographs of the mortar specimens, exposed at elevated temperatures
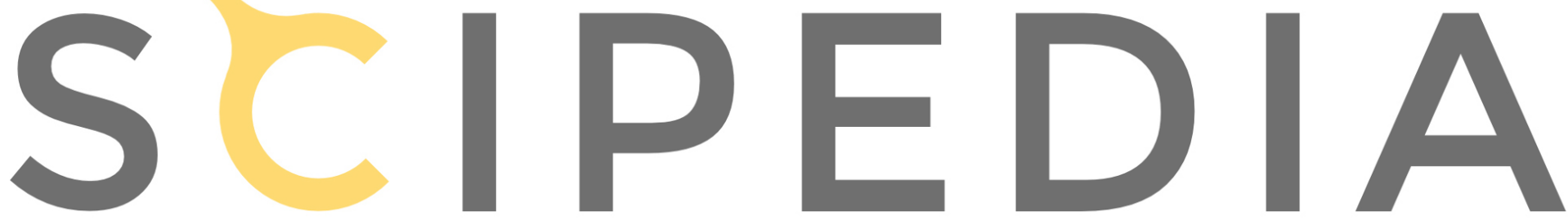

Register for free at https//www.scipedia.com to download the version without the watermark 


\section{CONCLUSIONS}

The performance of building materials at elevated temperatures, is a significant factor influencing their maintenance and preservation state. In the present study, an effort was made to assess the resistance of mortars made by contemporary and traditional binders, showing that the initial strength level of materials may not be the key element of their performance.

According to the research results, cement-based mortars (composition C) presented significant decay when exposed at elevated temperatures. High volume reduction was recorded (2-4\%), extreme increase of porosity (values are tripled, $8 \rightarrow 24 \%$ ), while mechanical properties were significantly influenced. At $600^{\circ} \mathrm{C}$ strength loss was around $45-75 \%$, with the flexural strength to be severely affected (flexural strength: $10 \rightarrow 2.5 \mathrm{MPa}$, compressive strength: $60 \rightarrow 38 \mathrm{MPa})$. At $1000^{\circ} \mathrm{C}$ flexural and compressive strength was reduced around $85-90 \%$.

When lime was added in the mixture (CL), the physical properties were enhanced throughout the elevated temperatures. Mechanical characteristics were maintained (with a slight increase) up to $400^{\circ} \mathrm{C}$ and were further reduced at $600^{\circ} \mathrm{C}(50 \%$ for compressive and $80 \%$ for flexural strength). At $1000^{\circ} \mathrm{C}$ they were minimized.

In the case of lime-based mortars, a slight volume change was recorded, whereas the mass change was extreme (8-20\%). Porosity values were almost doubled $(16 \rightarrow 30 \%)$ except for the pure lime mortar (L), which presented the lowest fluctuations (29-34\%). Mechanical properties and especially compressive strength was enhanced up to $600{ }^{\circ} \mathrm{C}$ (around $80 \%$ in the case of LP) and were minimized at $1000^{\circ} \mathrm{C}$. The pure lime mortar (L) was the one to present the lowest strength loss at 800 and $1000^{\circ} \mathrm{C}(20-30 \%)$.

It is therefore asserted that, contradictory to the cement-based mortars, lime-based binding systems (C:L, L:P, L:P:C) presented a generally good behavior, up to the limit of $600^{\circ} \mathrm{C}$, maintaining both their physical and mechanical properties. However, at the highest temperatures of 800 and $1000^{\circ} \mathrm{C}$ cement-based mortars seemed to present a better performance.

Concluding, it is noticed that the binding system significantly influences the overall behavior of the mortars at elevated temperatures. The addition of lime in traditional or contemporary mortar systems seem to be benefited in the case of extreme temperatures. However, more oriented research should be made in order to further document the physico-chemical reactions taking place in the mortar matrix.

\section{REFERENCES}

[1] Lea F. and Stradling R. The resistance to fire of concrete and reinforced concrete. Engineering (1922) 114:395R-396R.

[2] Georgali B. and Tsakiridis P.E. Microstructure of fire-damaged concrete. A case study. Cement Concrete Comp (2005) 27:255-59.

[3] Chan Y.N., Peng G.F. and Anson M. Residual strength and pore structure of highstrength concrete and normal strength concrete after expose to high temperature. Cement Concrete Comp (1999) 21:23-27.

[4] Ingham J.P. Application of petrographic examination techniques to the assessment of fire-damaged concrete and masonry structures. Mater Charact (2009) 60:700-9.

[5] Khoury G.A. Effect of fire on concrete and concrete structures. Prog Struct Eng Mat (2000) 2:429-47. 
[6] Chung H.W. and Law K.S. Assessing fire damage of concrete by the ultrasonic pulse technique. Cement Concrete Aggr (1985) 7:84-8.

[7] Pachta V., Triantafyllaki S. and Stefanidou M. Performance of lime-based mortars at elevated temperatures. Constr and Build Mat (2018) 189:576-84.

[8] Krzemien K. and Hager I. Post-fire assessment of mechanical properties of concrete with the use of the impact-echo method. Constr Build Mater (2015) 96:155-63.

[9] Stefanidou M. and Pachta V. Influence of perlite and aerogel addition on the performance of cement-based mortars at elevated temperatures. In: Int. Conf. SBE19, Sustainability in the built environment for climate change mitigation (2019).

[10] RILEM TC 129 MHT. Test methods for mechanical properties of concrete at high temperatures and RILEM TC HTC. Mechanical concrete properties at high temperaturemodelling and applications; Part 1: Introduction. Mater Struct (2007) 40:841-53

[11] RILEM TC 200-HTC. Recommendation of RILEM TC 200-HTC: mechanical concrete properties at high temperatures - modeling and applications Part 1: Introduction - General presentation. Materials and Structures (2007) 40:841-53.

[12] EN 1991-1-2 2002. Eurocode 1: Actions on structures - Part 1-2: General actions Actions on structures exposed to fire. European Committee for Standardization (Brussels).

[13] EN 1992 2004. Eurocode 2: Design of concrete structures - Part 1-2: General rules Structural fire design European Committee for Standardization (Brussels).

[14] ISO 834-11 2014. Fire resistance tests - Elements of building construction - Part 11: Specific requirements for the assessment of fire protection to structural steel elements. International Standards Organization.

[15] BS 476-3 2004. Fire tests on building materials and structures. Classification and method of test for external fire exposure to roofs. British Standards Institute (London).

[16] Russo S. and Sciarretta F. Masonry exposed to high temperatures: Mechanical behaviour and properties - An overview. Fire Safety Journal (2013) 55:69-86.

[17] Pachta V., Triantafyllaki S. and Stefanidou M., The impact of elevated temperatures at the properties of lime-based mortars. In: J.I. Alvarez et al. (Eds): 5th Historic Mortars Conference, HMC 2019, RILEM Proceedings, PRO 130 (2019), pp. 1156-1165. 